\title{
Military Combat Work: The Reconstitution of the ANC's Armed Underground, 1971-1976
}

\author{
Thula Simpson* \\ University of Pretoria
}

\begin{abstract}
This article describes the African National Congress (ANC) underground in South Africa in the years immediately preceding the 1976 Soweto uprising, and it makes three main contributions to the existing literature on the topic. The first is primarily descriptive, and involves providing greater detail than has hitherto been offered on the ANC's clandestine organisational presence in neighbouring Swaziland, Mozambique and Tanzania that facilitated the revival of the underground in South Africa. The other two are of value in analysing the longer history of the ANC's armed struggle: firstly, the article describes Military Combat Work, the training regime offered to Umkhonto we Sizwe cadres in the Soviet Union, and which formed the template that was to guide the prosecution of the armed struggle in future years. The second involves backdating to the pre-Soweto uprising period, many of the challenges facing the armed struggle that historians have hitherto characterized as being a post-June 1976 phenomenon. This article describes the Challenges the ANC in exile faced hosting the hundreds of cadres that joined its ranks after recruiting work within South Africa began in the early to mid-1970s.
\end{abstract}

Key words: Umkhonto we Sizwe, African National Congress, Soweto uprising, armed struggle, Military Combat Work, Black Consciousness

The early Seventies saw the ANC engaged in trying to absorb a stream of South African youths seeking to join its armed wing, Umkhonto we Sizwe (MK). This exodus of youths was a consequence of political volatility inside South Africa following the apartheid government's attempts to forcibly repress the nascent student movement within the country. The article will show how the ANC capitalised on this ferment by establishing an organisational structure in neighbouring Swaziland that was able to establish connections with the most militant elements of the student movement, as well as with the remnants of the ANC's internal underground, and arrange through these channels for youths to be recruited and subsequently escorted out of the country to receive military training with MK. The article then describes how this new generation of cadres were prepared for war, and it outlines in detail the training the most promising of the recruits received in Military Combat Work (MCW), a course offered in the communist bloc countries of Eastern Europe. MCW served as the programme employed by the ANC to develop its armed struggle in the years following the Soweto uprising. Finally, the strains on the ANC's capacity to accommodate the combatants it received in the months leading to June 1976 is described, and it is explained how these difficulties motivated the movement to focus, from the beginning of 1976, on building up its armed force within South Africa's borders. In sum, the piece offers a narrative that analyses the manifold processes including recruitment, mobilisation, training, and deployment - undertaken by the ANC in the early $1970 \mathrm{~s}$ in its effort to reconstitute its military wing as a force capable of overthrowing the apartheid government.

\section{From BC to MK}

MK was established in 1961 by a group of ANC and South African Communist Party (SACP) activists, led by Nelson Mandela and Joe Slovo of the respective organisations. It was given the responsibility of partaking in acts of sabotage designed to give greater force to the mass political campaigns that the Congress Alliance (the umbrella organisation of which the ANC was a part) was engaged in at the time. The vision of MK's founders was that such applications of violence would raise the spectre of civil war, and that this would induce South Africa's white minority to 
'wake up' and engage in negotiations to achieve peaceful political change before that stage was reached. This estimate proved a miscalculation because in practice, the ruling National Party instead resolved to annihilate the ANC and SACP as organised entities within South Africa. By the mid-1960s this was largely achieved; the organised underground structures of these two movements inside South Africa were eradicated by the mid-decade (Simpson 2009a: 313-4).

This was the political climate into which the Black Consciousness (BC) movement emerged amongst black South African youths in the late 1960s. By the early years of the following decade, a number of groups and organisations influenced by the ideals of the leading thinkers of the $\mathrm{BC}$ political tendency were in existence.

*Email: thula.simpson@up.ac.za

The two strongest and most important were the South African Students' Movement (SASM), which was formed in 1972, and the National Youth Organisation (NAYO), established the following year. Though the members of these and other BC influenced organisations were generally strongly anti-government, they initially tended to restrict their direct articulations of political grievances to private discussions, whilst opting for circumlocution in the public arena, where they channelled their dissent into cultural modes of expression such as music, poetry and dance. However, they found that this offered scant protection from the violence of the authorities who routinely arrested, detained and brutally interrogated them regardless. This repression provided an impetus for the radicalisation of the youth movement, an increasing number of whose members began to feel that BC policies - but not, in most cases, in an important distinction that must be made, the ideology of the Black Consciousness organisations - which featured a pragmatic commitment to non-violence as the necessary price to be paid for continued legal or semi-legal existence, and being able to partake in open campaigning, was fatally flawed. For this reason, within a couple of years of SASM and NAYO's formation, radical elements in both had begun discussing, and, in some cases implementing, plans to engage in armed resistance against the state. Through mass arrests, the Police crushed the first of these attempts, but these victories proved counterproductive because the violence accompanying them served to inflame the situation, leading to some of the youth activists endeavouring to seek out the ANC and Pan-Africanist Congress, South Africa's two banned liberation movements, who each possessed military wings able to provide access to sophisticated weapons and instruction in how to use them (Brooks and Brickhill 1980: 75-6, 81-7).

Amongst the dozens of individual cases illustrative of this trend was that of Naledi Tsiki, who, when he left Soweto in 1971 to attend St. Agnes High School in Lesotho, was already influenced by the ideas of the Black Consciousness movement. Whilst abroad he was radicalised further by being exposed to political literature banned in South Africa, as well as by friendships he formed with student members of the Basotho Congress Party, many of whom were receiving scholarships to study in Eastern Europe. Tsiki wished to join them, but found the bursaries reserved for citizens of Lesotho; he was, however, aware of another passage abroad, namely through the ANC, which was known to be looking to recruit South African youths studying abroad into $\mathrm{MK}$, and he initiated various efforts to contact the organisation in order to exploit this opportunity. Tsiki was contacted whilst in Lesotho by Mosima 'Tokyo' Sexwale. The two knew each other well because their families lived about three houses away from each other in the Dube section of Soweto, and Sexwale was a friend of Tsiki's older brother. Sexwale travelled to Lesotho partly to access political 
literature banned in South Africa, but whilst there, he also held conversations with Tsiki in which he divulged that he had also been influenced by the Black

Consciousness ideology (leading him to join the South African Students' Organisation [SASO] which was a part of the Black Consciousness Movement), and had initiated efforts of his own to contact the ANC, including a visit to Botswana in 1972 that did not succeed, but had yielded a meeting with members of the Zimbabwe African People's Union (ZAPU), who provided him with cartridges. Henceforth, whenever he returned to Lesotho or Tsiki arrived back in Soweto, the two continued their political discussions. Then, from October 1973, when Tsiki returned to Soweto on a permanent basis, the pair formed a discussion group into which they invited likeminded youths in the township. This group persevered with the attempts of its founders to contact the $\mathrm{ANC}$, and first concentrated on Botswana which they felt, based on previous experience, representing marginally their best hope of success. However, they had a rethink when some of their friends, who departed to that country with the same hope, returned feeling quite hostile to the ANC after having failed to do so. From this point onwards the group opted to focus on contacting ANC structures closer to home in Soweto itself, and as part of this they got in touch with Winnie Mandela late in 1973, via a friend of theirs named Nzima Mehlomakulu, who worked as her gardener, cleaner and occasional chauffeur. They hoped that as a living symbol of the ANC she may have connections with the movement, but she said she did not, and therefore this, like their other initiatives to locate representatives of the organisation in Soweto, ran aground. ${ }^{1}$

There was an ANC presence in the Johannesburg area at the time. It consisted of ANC veterans who had been released from prison after serving sentences for their involvement in underground political activities in the early 1960s. They referred to the body that they formed as alternatively the 'Main Machinery' or 'General Structure'. The Main Machinery's chairman was John Nkadimeng, who had been freed from incarceration in 1966; he was joined in following years by Alois Manci, Martin Ramokgadi and Henry Makgothi; and this core would later be augmented by Joe Gqabi, who joined after being released from prison in August 1975. This collective had to operate with great circumspection, because after release they operated under a variety of restrictions such as house arrests, banning orders and close police surveillance. Nevertheless they tried to advance the ANC's interests as far as they could. One initiative they undertook in the early 1970s was to spread the organisation's influence within the student movement. Elias Masinga, came from an ANC supporting family and was of student age. He had contact with Manci, and was mandated by the underground to infiltrate student groups. In 1973 he joined SASM and became its vice president the following year, in which he also joined another student organisation named the Ekukhanyeni Cultural Youth Club (EYC), becoming its president in 1975. He then engaged in recruiting people and distributing banned political literature within the structures of these groups. The ANC networks established within these organisations received advice and counsel from the senior leaders within the Main Machinery. In these contacts, the youths were warned that state repression would inevitably intensify in the future, and they were advised to establish underground cells to enable them to withstand the pressure. Based on this advice, SASM created cells called 'shadow committees' in 1974. Within these committees, the question of engaging in armed struggle was raised, but there were deep divisions on the matter and no consensus was reached (Brooks and Brickhill 1980: 81-7; Houston and Magubane 2006: 381-3; Motapanyane 1977: 53-4; Suttner 2008: $63-4){ }^{2}$ 


\section{The Recruitment Squads}

The Main Machinery had no regular contact with the ANC based outside South Africa in 1974, and so would not have been able to arrange for many activists to leave the country to receive military training with MK. In 1975 the situation began to change, with the ANC deploying Thabo Mbeki, one of its leading officials, to establish a structure in neighbouring Swaziland. Mbeki's group soon contacted the Main Machinery and instructed the Johannesburg-based structure to embark on recruiting people to leave the country to receive military training with MK (Simpson 2009b).

Mbeki's collective activated other groups besides the Main Machinery into underground work on the ANC's behalf. This set in motion a dynamic which served to fuse the various internal networks into a unified structure, because as these groups began expanding their work to fulfil the demands being placed on them from Swaziland, they started encroaching on each others territory; and as they became acquainted with each other, they opted to combine their efforts, and this contributed to the consolidation of the underground.

In one example of this process, Mosima Sexwale happened to be based in Swaziland at the time of Mbeki's arrival: he had moved there in 1974 to further his studies at the Kwaluseni campus of the University of Botswana, Lesotho and Swaziland, where he became highly active in student politics, including becoming chief prosecutor of the university's SRC. Sexwale was soon drawn to the attention of Mbeki's group and in the early months of 1975 they recruited him into the ANC. When Sexwale reported this news back to his colleagues in the discussion group he had formed with Tsiki in Soweto, they urged him to deepen his ties with the ANC, whilst they, galvanised by the information, reconstituted themselves into 'operational units' devoted to recruiting militants in the township to go abroad and receive military training with $\mathrm{MK}^{3}$

The operational units soon became aware of another group operating on the ANC's half in the Soweto area. This co-existent unit had its origins in the early months of 1975 in a discussion group formed in Soweto to discuss radical literature, including the classics of Marxism and the BC movement. The members of the group were Siphiwe Nyanda, a sports reporter for a local newspaper, and in whose house they met, Stanley Nkosi, who was then a student member of SASO, and Kgalema Motlanthe, a mutual friend of the others. As part of their political education, the trio would each listen to broadcasts of the ANC's station Radio Freedom. They decided to contact the ANC abroad, and managed to do this in October 1975, when Nyanda travelled to Swaziland, where he met Keith Mokoape, a member of Mbeki machinery. Mokoape told Nyanda to return to Soweto and remodel the discussion group into a recruiting cell involved with enlisting people from the township to leave the country and join MK. Nyanda agreed, and he and his colleagues established a recruiting cell in Soweto into which they invited a fourth individual named George Nene. The work they accomplished soon became widely known in the township, including to the 'operational units', and these two bodies reconstituted themselves into a joint 'recruitment squad' soon after they became aware of each others existence. ${ }^{4}$ Meanwhile, Ian Deway Rwaxa had been recruited into the operational units in September 1975, only to subsequently be recruited into the Main Machinery. Through Rwaxa the Main Machinery became acquainted with the recruitment squad, and these two structures, which had previously been unaware of each other, began collaborating. ${ }^{5}$ These examples indicate how the establishment of the Mbeki 
underground served to facilitate the expansion and coalescence of the various components of the internal underground which it activated.

As noted, rumours of the recruiting work being undertaken on the ANC's behalf spread quickly within Soweto, and the buzz spread quickly to the South African Security Branch. The police identified Swaziland as the area from which the danger emanated, and they identified Sexwale as a troublemaker over whom they would need to keep a watchful eye. Towards the end of 1975 they began enquiries in Soweto as to his whereabouts, but they failed to land him. During the course of their questioning of the Sexwale family, the police made it quite clear that their line of inquiry was headed towards Tsiki. Sexwale's sister warmed Tsiki of this. When Tsiki discovered that the police had been looking for him at his family home, he decided to flee the country. He was told of the police visit from Selaelo Ramusi, one of his colleagues in the recruitment squad. Tsiki exited the country for Swaziland sometime in late November/early December 1975. There he met Keith Mokoape, and Albert Dhlomo, who was Mbeki's deputy in the ANC structure in Swaziland. In their discussions the three made an agreement involving Tsiki remaining abroad to receive between three to six months of military training with MK, thereby allowing the situation in Soweto to cool in the interim, whilst the others would monitor the situation within South Africa during his absence and see whether conditions were conducive for him to be infiltrated upon his return. Tsiki was inducted into MK by Dhlomo after the plan had been agreed, but he requested to first be allowed to return home briefly to tie up some loose ends before he commenced his military career. Amongst other things, he wanted to formally hand over control of the operational units to a colleague named Christopher Manye. This wish was granted, and Tsiki completed these formalities during a three day sojourn in Soweto. It was whilst trying to hitchhike back to Swaziland that he had a surprise encounter whereby he was collected by none other than Selaelo Ramusi, who, it transpired, had also received instructions to report to the kingdom and was on his way there, when, to his surprise, he saw his colleague standing by the roadside. The two travelled the rest of the journey to Swaziland where they were told that they should be prepared to leave for Mozambique that same night. ${ }^{6}$

The member of the ANC's structures in Swaziland responsible for leading cadres into Mozambique was Ablon Duma. However, owing to the Swazi government's prohibition of such activity, this work had to be conducted clandestinely. The procedure Duma followed when leading Ramusi and Tsiki across the border in the first week of December 1975 was the standard arrangement used in these crossings; it involved him and the recruits being driven to approximately 2 kilometres of the border post at Lomahasha/Namaacha (to give the names by which it was known in Swaziland and Mozambique respectively), where they disembarked and undertook the rest of the journey by foot, marching through the bush in the vicinity of the checkpoint, and entering Mozambique by crawling under the fence demarcating the boundary between the two countries. On the other side they marched until they arrived at the collection point where Duma had arranged with Lennox Tshali, the ANC's representative in Maputo, to leave them. Tshali arrived to collect the recruits in the company of officials from Frelimo, Mozambique's governing party. The presence of Frelimo representatives on these excursions bespoke the very different attitude of the authorities in Maputo towards ANC underground activity when compared with their Swazi counterparts. In fact this collaboration was sufficiently close that whenever Duma and Tshali failed to make their rendezvous, the former would simply hand the recruits in his possession over to the care of Mozambican 
border guards who would ensure their safekeeping until transport arrived from Maputo; such was the arrangement a few days before Christmas 1975 when Duma delivered Sexwale and three other recruits to Mozambique. ${ }^{7}$

To house its military cadres in Maputo, the ANC utilised a variety of what it termed 'transit facilities', which were in fact properties dotted across the city. Amongst these were apartments in a block of flats called 'Pensáo', which was inhabited mostly by white tenants, as well as a variety of residents that Lennox Lagu himself inhabited, including one near Machava prison and another located in the vicinity of the buildings of Mozambique's Ministry of Immigration. MK cadres residing in this accommodation fell into three broad categories: some had been recruited by, and transported to Mozambique by the ANC; others had been recruited by the ANC in other countries but travelled under their own auspices to Maputo, where they handed documentation proving their membership of the movement to Mozambican officials, who saw to it that they were conveyed to local representatives of the organisation; finally, there were those who arrived in Maputo wanting to join the ANC having had no previous contact with the organisation: these were escorted by Frelimo officials to a refugee camp in Avenida de Brazil in Maputo. This was a camp in which ANC functionaries operated, and they would ask the newcomers whether they preferred to receive political education or military training. ${ }^{8}$

Those who chose to become soldiers joined the other MK cadres in the transit residences. For the guerrillas in the residences, the next leg of their journey involved them being flown in groups of five on East African Airways jets bound for Tanzania, where the ANC possessed two of what it called 'transit camps', which were a couple of large dilapidated houses in the vicinity of Dar-es-Salaam. These camps were led by three MK veterans from the ' 60 s of whom one, Joseph Nduli, served as overall commander. At these camps the MK combatants received their first military training, involving basic drill, discipline, orders and marching. The guerrillas also held extensive discussions with their commanders over what life in MK would entail: in these consultations Nduli recounted to them his combat experiences in Rhodesia in 1967, and of how he separated from his platoon and entered South Africa on his own, progressing as far as Durban, before retreating to Swaziland where he had been stationed until receiving his summons to go to Tanzania to command the camps there on a temporary basis. In addition, senior ANC officials like Eric Mtshali, who was the organisation's chief representative in Tanzania, Moses Mabhida, Mzwai Piliso, and Oliver Tambo, would arrive at the camps and deliver political lectures in which the basic tenor was that having completed their training, the role of the recruits as MK fighters would be to return to South Africa and militarily overthrow the apartheid state, thereby allowing the ANC to claim power and begin immediately implementing its programme based on the Freedom Charter. For their part, when probed for their feedback, the recruits almost uniformly stated that they aspired to the same. Of all the ANC leaders they encountered in Tanzania, the MK combatants found Oliver Tambo most impressive: to them he was solicitude personified; rather than addressing them as a group, he spoke to each individually, referring to them as 'comrade' and enquiring about the state of their health and the quality of their food. ${ }^{9}$

For security reasons the MK combatants were forbidden from making unauthorised departures from the camps, and the same consideration meant that even their contacts with each other were circumscribed. An average day in the camps proceeded roughly as follows: the soldiers would rise at roughly $0600 \mathrm{Am}$ and do exercises for about an hour before having breakfast. They would then relax until around 0900 AM when they would play football for approximately an hour, after which 
they would listen to radio news broadcasts, and then assemble in small groups to stage political debates based on the bulletins. After lunch at midday, they would rest until $1500 \mathrm{PM}$, when they would receive a half-hour class on the theory of guerrilla warfare, and rest until supper at 1800 PM. From about 1900 PM they would spend around an hour singing freedom songs, before resting until 2300 PM, which was bedtime. Throughout the day, different groups amongst the guerrillas would be given shifts of guard duty, protecting the camps. This hermetic existence would only be interrupted when ANC officials arrived to take the combatants in groups of two and three to Dares-Salaam, where they received medical check-ups, inoculations, and photographs for tickets, visas and medical certificates, to be used to validate fake Tanzanian passports that could be employed in countries such as Swaziland where MK activity was officially prohibited. ANC underground operatives received special codenames in each country through which they passed, and the pseudonyms that they received in Tanzania were used in these counterfeit documents: for example, Naledi Tsiki's codename in Tanzania was 'Chris', and his fake passport was issued in the name of 'Christopher Pitje'. ${ }^{10}$

\section{Eastern Bloc Training}

The cadres that the ANC identified as being the most promising of its component in the Tanzanian camps were selected to undertake advanced training in the Soviet Union. Most of these were flown to Moscow Airport where they were met by KGB detail who whisked them through customs and arranged for them to be transported to the city's eastern suburbs where there was a Tsarist era mansion that over time had been converted into a training facility, with some of its rooms becoming lecture halls. The training took place on weekdays, and as part of their instruction the militants were given a 'crash course' in Russian that was offered in order to enable them to read newspapers and magazines, understand radio and television broadcasts, and communicate in theatres, circuses, museums, parks and shops, during their rest periods over the weekend. Besides these excursions into central Moscow for entertainment purposes, the other major departure from their daily routine in Russia were the visits they occasionally received from ANC notables such as Moses Mabidha, Joe Modise, Eric Mtshali, Mzwai Piliso, Joe Slovo and Oliver Tambo, when such luminaries happened to be visiting the Soviet Union. ${ }^{11}$

The combatants were usually given a couple of days to acclimatise before commencing with their lectures. Though the emphasis between subjects varied from course to course, the basic outline of the curriculum offered remained the same. Of the subjects taught, 'political science' formed the keystone of the arch because it advanced the ideology which informed the philosophy of war on which the military training was grounded. Through an exposition of cosmology, geography and evolution, 'politics' first explained the arrival on planet Earth of the first Homo sapiens, before describing the subsequent progress of the species by means of the Marxist doctrine of historical materialism, that theory of how hunter-gathering spawned slavery, which birthed feudalism, which begot capitalism and the modern age, which was characterised by capitalism's disfiguration into imperialism, and the overthrow of imperialism by socialism and communism. To be sure, in almost every group there were recruits still under the sway of Black Consciousness ideas who would question the relevance of this class-dominated paradigm to their lived experiences, but the Soviet instructors - who, the cadres had to admit, were generally very well versed on South African politics - soon patented a response that managed to 
wrong foot if not completely disarm them by pointing to the ANC's own political programme, as outlined in the Freedom Charter, which stressed that the conflict was not primarily racial in nature. The politics section of the course would then conclude with the recruits being taught that working class and national liberation struggles in industrialised and non-industrialised countries respectively formed the twin pillars of the global struggle for socialism. ${ }^{12}$

'Tactics' covered the various modes of fighting witnessed in struggles against imperialism from the Russian revolution in 1917 onwards, with seven distinct forms of revolutionary warfare being identified. The most basic of these was described as involving an individual worker sabotaging his or her workplace; next in complexity were raids undertaken by sabotage squads of up to five persons on targets in rural and urban areas; whilst more sophisticated were 'platoons' of up to fifty persons involved in attacking the enemy's communication lines. It was in the next phase of conflict that the partisans began to exhibit the features of a regular army. At this stage, which was to be fought by 'guerrilla detachments' created from the fusion of three platoons, the insurgents would partake in attacks on enemy encampments and armed columns, whilst also embarking on the conquest and defence of territory. These enlarged responsibilities would require the infantry units of the detachments to be supported by specialised logistics, medical, reconnaissance, communications and sabotage teams of between three and six people, as well as extra sections of equal size charged with handling complex weapons such as anti-tank guns, large machine guns, grenade launchers and anti-aircraft missiles; it was to coordinate the activities of these manifold parts that the detachments would require the appointment of a military commander to lead them, assisted by a commissar responsible for organising political education for the soldiery, and overseeing the process of political outreach to civilian populations in the conquered territories. These guerrilla detachments would then grow in strength until between three and five of them could combine (with the supporting logistics, medical, reconnaissance and other sections growing into 'platoons') to form 'guerrilla brigades' that would prosecute larger combat operations against the enemy; then when four of the brigades combined (during which the support sections would expand threefold), they would create 'guerrilla formations' devoted to the conquest of large towns and cities through conventional military methods. This seizure of the citadels would pave the way for the political leadership to claim power, during which the guerrilla army would transform itself into a conventional military force in the seventh and final stage of the revolutionary process. ${ }^{13}$

The balance of the remainder of the subjects covered the military techniques available to a guerrilla army in executing such tactics. 'Demolition' (also referred to as 'sabotage' training), was described to the recruits as representing the single most effective means of subverting a government, with railway lines, sewerage and water pipes, pylons, bridges and telephone poles being mentioned as the most effectual targets of a sabotage campaign. As part of demolition training, the science behind how a number of incendiary devices worked was taught, as well as the likely effect these explosives would have if used, and the objectives on which they would be most impactful. 'Reconnaissance' detailed how to conduct individual attacks, emphasising especially the need to observe the target, and, preferably, photograph it before commencing with an assault. 'Topography' covered orientation, with lessons on reading, drawing, storing and marking targets on maps being offered. Finally, 'fire training' dealt with the use of firearms: it involved the study of ballistics, and provided instruction on how a variety of weapons manufactured by Warsaw Pact and 
NATO countries could best be stored, cleaned, assembled, disassembled, fired and prevented from misfiring. ${ }^{14}$

\section{Military Combat Work as a Concept of the Armed Underground}

The central subject in the course was 'conspiracy' or 'Military Combat Work' (MCW), which fused the lessons of all the other subjects together into a coherent strategy outlining how a political movement could build a military force capable of leading the armed seizure of power. The fundamental tenet underpinning MCW was that in its essence, war was a form of class struggle, with MK combatants being taught that in their case, the 'National Liberation Movement', i.e. the ANC, represented 'the Vanguard of the oppressed \& patriotic forces', whilst its antagonist, the State (defined as 'an organ for the oppression of one class by another'), served an analogous function on behalf of the exploiters. The inspiration for MCW came from the writings of Lenin, and the training echoed his call for the creation of a small, tight core of political activists - akin to the Central Committee of the Bolshevik Party in 1917 - to formulate 'strategy', involving devising plans for coordinated military action on a nationwide scale, as well as issuing directives on political objectives, alliances and campaigns. This nucleus was then tasked with creating sub-organs of itself at 'national', 'regional', 'provincial', 'city', 'district/area', 'factory' and 'shop' levels in order to ensure that political and military 'tactics' consistent with its overarching guidelines were implemented on the ground. These substructures of the central committee were then each mandated to create military appendages (in the process turning themselves into what were called 'political-military committees') to assist them in developing tactics responsive to the movement's overall strategic perspectives, whilst the committees were also each to establish security/intelligence sections that would have a role in implementing - but not devising - policy. ${ }^{15}$

The liberation movement's first challenge in creating a guerrilla army was defined as involving it training up a core of military, political and security/intelligence units that it could deploy to embark on the mobilisation of the masses, thereby creating a broad popular base on which its armed force could recruit its strength. The mobilising work carried out by these units was to be overseen by the 'national' and 'city' level political-military committees working in conjunction with each other. In this process, the military underground - which would be comprised of 'combat forces' such as self-defence units, combat groups and sabotage squads that would operate in small cells and wield light weapons such as handguns, grenades, knives and explosives - was to collaborate with its counterparts in the political underground in distributing propaganda and organising protests, whilst during mass meetings, which formed the centrepiece of the mobilisation, as operatives of the political section attempted to radicalise the masses, the combat forces would guard participants, position bodyguards, organise sentries and generally maintain order, whilst cadres from the security/intelligence division would assist by organising locations for the gatherings, monitoring potential subversives, and establishing secure hideouts to which to retreat in the event of danger. As this work unfolded, the movement would gradually be able to identify the individuals from the wider population who were most enthusiastic about its message, and it was the role of the clandestine units on the ground to recruit these persons into the political underground, which was known in MCW terminology as the 'Political Army'; it was then the responsibility of the members of the combat forces to audit the Political Army's personnel, identify the most zealous and capable individuals therein, and induct these people into the 
guerrilla force, which was termed the 'Revolutionary Army'. In such manner the rebel forces would progressively accumulate in numbers. Then, as the masses were gradually brought into the underground, the role of the trained combat forces would progressively shift as its members became responsible for training and commanding the armed forces whilst still being responsible for undertaking specialised operations themselves. In the lexicon of MCW, the kind of officers' corps that the combat forces were to become was referred to as the 'Organised Advanced Detachment' of the Revolutionary Army, whilst the soldiers over whom they would lead were called the 'Revolutionary Armed People'. The process by which these two parts of the guerrilla force would be built was termed 'Combat Work', and represented one half of building the Revolutionary Army. The other half involved establishing 'Units of the Enemy Army and Police', and was called 'Military Work'. As with Combat Work, this enterprise would be overseen by the 'national' and 'city' level political-military committees, who would jointly supervise the work of units on the ground that would strive to form cells within the state security force apparatus; the task set for these cells was to worm away at the edifice of the enemy force apparatus, and, at the decisive moment, contribute to their final collapse by either deserting or defecting. ${ }^{16}$

MCW training focused especially on the skills that such political, military and security/intelligence units would need in order to successfully undertake mobilising and organising work in the opening phase of the conflict. Trainees were drilled in different methods of covertly organising workers, recruiting agents, disseminating propaganda, conveying and receiving messages, contacting strangers, employing camouflage, and conducting intelligence and counterintelligence work. Above all they were taught about the cell system, involving each member of the underground recruiting three individuals who would each recruit three more, who all would recruit three others, etc. etc., thus enabling the underground to mushroom, but in a way that each member of the network only knew the identities of the individual who had recruited them and the three persons they themselves had recruited, thereby insulating the rest of the structure from police hostility. Accordingly, as part of their training, the cadres were taught that if captured and threatened with torture or any other form of intolerable cruelty, they should reveal all: if they had abided by the rules of the cell system, the instructors told them, the underground as a whole would be safe. ${ }^{17}$

Whereas the lessons on 'tactics' identified seven distinct military forms of revolutionary warfare, $\mathrm{MCW}$ discerned around five political phases of revolutionary conflict into which these military tactics were component parts. The first political phase of the conflict involved the mobilisation and organisation of the masses, and has already been described. The next stage was 'people's war', which was reached when the Political and Revolutionary Armies had grown sufficiently to be able to draw large numbers of the populace into confronting the organs of state power politically and militarily. When political resistance had become generalised and the Revolutionary Army had grown to the point where it could field 'guerrilla formations' (which, as stated in the lessons on tactics, would fight the stage of revolutionary warfare preceding the seizure of power) and engage in 'open armed struggle' involving the conquest of large swathes of territory, the struggle was defined as having reached its next stage, namely a 'revolutionary situation', in which the existing 'ruling class' could no longer 'rule in the "same old way". This interregnum, in which neither the government nor the rebels were in overall control, would then serve as the prelude to the penultimate phase of the revolutionary process, which would be a 'general insurrection' leading to the seizure of state power. It was the job of the liberation movement to identify the correct moment within a revolutionary situation in 
which to call an uprising. The responsibility for identifying the moment would fall on the Revolutionary Army; this was because the criteria on which the choice would be made was described as being essentially military in nature, with the correct timing featuring the state being caught unawares, the security forces widely dispersed, and the liberation army ready to go on the offensive with immediate effect. If the 'vanguard' political organisation had successfully applied MCW by creating a political underground, if it had armed and radicalised the masses, and if it had created cells within the enemy army, then, subject to the results of the Revolutionary Army's survey of the disposition of the enemy forces, a nationwide uprising could be called. If such a declaration were issued, upon receiving its summons to rise, like wildfire the Revolutionary Army would spread, seizing railway stations, airports, military bases, harbours, bridges, strategic roads, radio stations, banks, government buildings, power stations and industrial plant, whilst also launching ambushes and sabotage raids, and sowing minefields, erecting barricades, and instigating street fighting. By thoroughly disorienting and paralysing the enemy forces, this blitzkrieg would create the political space for a mass rising to succeed in toppling the regime. This would prepare the ground for the seizure of power, which was the final phase of the revolutionary process. During this transition, the revolutionary movement would arrive and fill the power vacuum, and begin to 'immediately dismantle the old, reactionary state apparatus and create a new, democratic one'. This would herald the dawn of a 'national democracy' in which 'people's power', defined as a political order featuring the political hegemony of the proletariat, would be established. However, during this changeover, the Revolutionary Army would receive no respite, because in the process of its duration, it would be charged with transforming itself into a permanent, standing military force capable of defending the new order against what was seen to be the inevitable challenge from the temporarily eclipsed counter-revolutionaries. ${ }^{18}$

The aspect of the Eastern Bloc training that has been described thus far involved the cadres being given a detailed theoretical outline of what revolutionary warfare entailed. The remainder of the training involved the cadres leaving the classroom for the field where they were offered practical lessons on how to put the theory into practice at ground level. This practical dimension of the training occurred at a number of bases. Once was in a forest a couple of miles east of Moscow where certain military techniques relevant to small underground units engaged in a sabotage campaign, such as manufacturing and detonating explosives, making depots for storing material, and handling and firing guns, were taught. ${ }^{19}$ Further practical training was offered in Sebastopol in the Crimea, in facilities that the Soviet Army itself used. There MK groups were drilled in fighting in large units such as guerrilla formations. Some of these contingents had the privilege of being led in their steps by their Soviet military counterparts who would occasionally conduct training sessions when representatives of the two forces brushed shoulders. ${ }^{20}$

One feature of $\mathrm{MCW}$ in its pure theoretical form that was entirely inapplicable in the context of the South African liberation struggle was the assumption that the central committee and the national and city level political-military committees of the revolutionary movement would be based in the same city, or at the very least in regular and close contact with each other. This premise did not apply in the ANC's case where, in the great dispersal of its personnel following the repression of the movement within South Africa in the early 1960s, its leadership structures had come to be spread across countries - even continents - making communications precarious. A part of the practical training offered in the Eastern Bloc, and one which was offered in the German Democratic Republic, tried to address this problem. The East German 
course offered to MK combatants was modelled on that offered by the local secret service, the Stasi, to intelligence operatives that it infiltrated into foreign countries. The rationale was that the tasks facing the secret agents and MK combatants were broadly similar: both would initially have to operate deep behind enemy lines on adverse ground and with no contact with their rear bases; they would therefore each have the challenge of surviving on this unfavourable terrain, building internal networks, and establishing communications with their external handlers. In these courses, the skills underground cadres would need in fulfilling these variegated tasks were taught: amongst these were different methods of communication, whether by code, invisible writing, dead letter boxes, safe cars or couriers - whether these messengers be witting or unwitting agents - whilst fighting methods were also taught, including sabotage, locating the enemy, engaging in close combat with pistols, and shooting, whether from stationary or moving cars, on land or underwater, and in the dark or the daytime. ${ }^{21}$

\section{From Recruitment to Training Squads}

Consequent to the activities of the various recruitment squads the ANC had working on its behalf within South Africa, a growing stream of recruits began leaving the country to receive military training abroad with MK as 1975 progressed. These recruits were sourced mainly from the Transvaal, Natal, and, to a lesser extent the Cape. $^{22}$

The ANC's capacity to handle this exodus was reaching its limits by the end of 1975. This was intimated to Siphiwe Nyanda and Stanley Nkosi in mid-December 1975 at a meeting they were called to in Swaziland after completing a routine delivery of two recruits to receive military training. In this meeting, Mokoape and Dhlomo told them that the ANC felt it had a lot of combatants receiving training in its external camps, and that the movement wished to focus henceforth on building up its armed force solely within South Africa's borders. When Nyanda and Nkosi returned to Swaziland early in January 1976 with another two recruits, they were told that they and their colleagues, Nene and Motlanthe, should reconstitute themselves into a leadership structure capable of establishing MK units within South Africa. The ANC strategy at the time regarding the establishment of a military force within South Africa centred on the establishment of a 'commanding unit', ideally consisting of three people, within the country. This unit would be connected, via courier, with a 'link man' based in an adjacent country, who would be their contact with the movement's external structures. Meanwhile, inside South Africa, the unit would be responsible for recruiting a subordinate cell of three persons. The members of this sub-cell would each then recruit three persons, who would each recruit three, thereby spawning an underground cell structure. Nyanda and Nkosi were told that besides initiating the formation of underground cells, their group would need to identify hideouts within South Africa where they could store firearms, explosives and political material, and offer political and military training. Finally they were informed that in their future visits to Swaziland, members of their cell would be given lessons in the use of the materials in which they would conduct the training. ${ }^{23}$

As part of its desire to shift the focus of its military mobilisation work inside South Africa, the ANC closed its Tanzanian 'transit camps' in the early weeks of 1976, and redeployed Joseph Nduli to Swaziland, ${ }^{24}$ where, operating under the codename 'Bushman' in the town of Luyengo, he offered courses training the prospective instructors of the internal MK units in different methods of sabotage. ${ }^{25}$ 
When Nkosi and Nyanda returned to Soweto, they discussed the mission with Motlanthe and Nene. The group expressed doubts about the feasibility of the plan based on the nature in which the police campaign to unearth the ANC's recruitment structures had escalated. The Special Branch was already making regular inquiries at Nene's house. Meanwhile, Nyanda had by then recruited so many people that his activities on the ANC's behalf were quite widely known in Soweto. The four decided to discuss their reservations with the external ANC, and Nyanda and Nkosi did this on their behalf when they travelled to Swaziland on 5 February 1976. When they raised their objections, they were told that that the external ANC would defer to the movement's judgement on the matter. The two then returned to Soweto and deliberated further. They eventually decided that Nyanda and Nene were too exposed and should leave the country, which they did in March 1976, taking along with them a number of recruits that they had each enlisted. ${ }^{26}$

Motlanthe and Nkosi were thus saddled with the task ob mobilising the MK units internally. On 10 February 1976, the pair travelled to Swaziland where Nduli provided them a four day course on making Molotov Cocktails (by wrapping a cloth doused in petrol around a bottle containing petrol, oil and tar) and T.N.T (from grease and potassium chlorate) to be used in sabotage attacks on bridges, walls and tunnels. Motlanthe and Nkosi returned to Soweto and stockpiled explosives and detonators after completing this course. They returned to Swaziland on 9 March to collect the potassium chlorate. Nkosi was to have returned with the potassium to Soweto, but Thabo Mbeki vetoed this after hearing that this would involve carrying the material on public transport. He arranged for a courier to convey the potassium, as well as political literature, at a later date. These were the only remaining materials that Motlanthe and Nkosi required in order to commence the training. These materials never arrived. The courier was intercepted by the police. Motlanthe and Nkosi first realised that something was amiss on 1 April on 1976, when the Security Branch arrived at the latter's house and interrogated the family on the whereabouts of his brother. Alex Madoda Nkosi had departed Soweto for Swaziland in March in order to receive military training. Whilst quizzing his father, they brandished Alex Nkosi's passport photo, which Stanley Nkosi knew was amongst the possessions of the courier. Apparently the security policemen did not know at that time about Stanley Nkosi's involvement with the ANC underground, but within a few weeks they were able to put the pieces together and they arrested him on 22 April, and his colleague Kgalema Motlanthe the following day (Houston and Magubane 2006: 391). ${ }^{27}$

\section{Conclusion}

Through these arrests, the Special Branch terminated the ANC's attempt to construct MK training structures within South Africa's borders. This article has shown how quickly and widely knowledge of the activities of the ANC's recruitment squads spread throughout the townships in which such enlisting units undertook their work. This security breach was surely unavoidable, because it is hard to see how a process that, in effect, entailed the mass disappearance of large numbers of able-bodied young people from specific areas in concentrated periods of time could possibly escape the notice of the broader populations living in the affected locales. Meanwhile, when a movement loses control of the dissemination of such information it cannot prevent it from being divulged to hostile audiences. It is thus inconceivable that the kind of recruiting work that the ANC underground engaged in during the period covered by this article, involving the enlistment of large numbers of people from particular areas 
to depart the country, could be conducted for long without coming to the attention of the police, unless the police had little or no presence in the communities in question.

This factor would have been one good reason for the ANC to seek to focus on mobilising its armed forces within South Africa's borders rather than trying to recruit large numbers to leave the country to receive training. However, the reason why the ANC took the decision in the early months of 1976 to try to recruit and train MK combatants inside South Africa, was because it knew that the burden of accommodating, feeding and training the tens if not hundreds of thousands of combatants that MK would have to field if it were to stand any chance of defeating a military as strong as strong as South Africa's, would quickly exhaust the budgetary resources of the movement and its allies, if it were forced to host these contingents outside the country. Any doubts of these constraints would have been dispelled by the difficulties the movement faced hosting the mere hundreds that entered its camps in the exodus of 1975. This influx however gave the ANC the nucleus of trained men it felt it needed to move to the next phase of the process of building up its revolutionary army, namely that of deploying these cadres to embark on mobilising armed forces within South Africa's borders.

Finally, this article has discussed how the training in MCW that MK cadres received abroad was relevant to this objective of internal military mobilisation. MCW touched on the major strategic challenges outlined in this conclusion, which are elaborated at greater length in the body of the essay, that the ANC's armed struggle faced. With what success MCW addressed these challenges, is an issue that needs to be interrogated in studies of the various attempts that the ANC, guided by MCW doctrine, initiated in the years following the Soweto Uprising, to develop MK as a force based within South Africa's borders that would be capable of combating the apartheid regime.

\section{References}

Books

Brooks, A. and Brickhill, J. 1980. Whirlwind Before the Storm: The Origins and Development of the Uprising in Soweto and the Rest of South Africa from June to December 1976. London: International Defence and Aid Fund.

Suttner, R. 2008. The ANC Underground in South Africa to 1976: A Social and Historical Study. Johannesburg: Jacana.

\section{Book Chapters}

Houston, G. and Magubane, B. 2006. 'The ANC Political Underground in the 1970s', in South African Democracy Education Trust (SADET), The Road to Democracy in South Africa: Volume 2 [1970-1980]. Pretoria: Unisa Press.

\section{Journal Articles}

Motapanyane, T. 1977. 'How June 16 Demo was Planned', Sechaba, 11 (2): 49-59.

Simpson, T.W. 2009a. 'The Making (and Remaking) of a Revolutionary Plan: Strategic Dilemmas of the ANC's Armed Struggle, 1974-1978', Social Dynamics, 35 (2): 312-329. 
Simpson, T.W. 2009b. 'The Bay and the Ocean: A History of the ANC in Swaziland, 1960-1979’, African Historical Review 41 (1): 90-118

${ }^{1}$ University of the Witwatersrand Historical Papers (hereafter UWHP), Karis-Gerhart Collection A2675 (hereafter KGC), Folder 39/Part I (hereafter 39/I), Howard Barrell interview with Naledi Tsiki, 26 Nov. 1990, 1244-6; UWHP, KGC, 25/III, 'Mosima Sexwale, deposition to the SA Police', 4 Feb. 1977, 6-7; UWHP, AD1901 Political Trials (hereafter PT), Box 64, The State Versus MG Sexwale and others, Court Record vol. 49, Naledi Tsiki's Statement to the Court, 5 Apr. 1978, 2384;

${ }^{2}$ UWHP, KGC, 28/III, 'Statement by Joe Nzingo Gqabi, Accused no. 7,' prepared for defence in S v Sexwale and others, 1978, 1-2; UWHP, KGC, 28/III, 'Statement of Elias Masinga,' prepared for defense in S v Sexwale and others,1977/8, 1-6, 19-20; UWHP, PT, Box 65 Folder 019 (hereafter 65/19), The State Versus MG Sexwale and others, Judgement by J. Myburgh, 5 Apr. 1978, 2330; Raymond Suttner interview with Murphy Morobe, 26 August 2003, p.14;

${ }^{3}$ UWHP, KGC, 39/I, Howard Barrell interview with Naledi Tsiki, 26 Nov. 1990, 1247-9; UWHP, KGC, 25/III, 'Mosima Sexwale, deposition to the SA Police', 4 Feb. 1977, 13-4.

${ }^{4}$ UWHP, KGC, 23/III, Stanley Nkosi, 'Confession,' 23 Apr. 1976, 4; UWHP, KGC, 23/III, Petrus Motlanthe, 'Confession,' 24 Apr. 1976, 4-5; UWHP, KGC, 23/III, Deposition to police by Stanley Nqobizizwe Nkosi, 19 July 1976, 3; UWHP, KGC, 39/I, Howard Barrell interview with Naledi Tsiki, 26 Nov. 1990, 1250

${ }^{5}$ University of the Witwatersrand Historical Papers, AD1901 Political Trials, Box 62, The State Versus MG Sexwale and others, Court Record vol. 25, Testimony of Ian Deway Rwaxa, 9 Feb. 1978, pp.1163, 1165; University of the Witwatersrand Historical Papers (hereafter UWHP), Karis-Gerhart Collection A2675 (hereafter KGC), Folder 39/Part I, Howard Barrell interview with Naledi Tsiki, Nov. 26, 1990, pp.1248, 1260-1.

${ }^{6}$ UWHP, KGC, 39/I, Howard Barrell interview with Naledi Tsiki, 26 Nov. 1990, 1250-1, 1253; UWHP, KGC, 25/III, 'Mosima Sexwale, deposition to the SA Police', 4 Feb. 1977, 18; UWHP, KGC, 26/III, 'Naledi Tsiki, deposition to the SA Police', 3 Feb. 1977, 3-5.

${ }^{7}$ UWHP, KGC, 25/III, 'Mosima Sexwale, deposition to the SA Police', 4 Feb. 1977, 14-5; UWHP, KGC, 26/III, 'Naledi Tsiki, deposition to the SA Police', 3 Feb. 1977, 6.

${ }^{8}$ UWHP, PT, 65/19, The State Versus MG Sexwale and others, Judgement by J. Myburgh, 5 Apr. 1978, 2265-7; UWHP, KGC, 25/III, 'Mosima Sexwale, deposition to the SA Police', 4 Feb. 1977, 16, 47; UWHP, KGC, 26/III, 'Naledi Tsiki, deposition to the SA Police', 3 Feb. 1977, 6.

${ }^{9}$ UWHP, PT, Box 60, The State Versus MG Sexwale and others, Court Record vol. 1, Testimony of Charles Buthelezi, 16 Jan. 1978, pp.29-30; UWHP, PT, 65/19, The State Versus MG Sexwale and others, Judgement by J. Myburgh, 5 Apr. 1978, 2263; UWHP, KGC, 39/I, Howard Barrell interview with Naledi Tsiki, 26 Nov. 1990, 1252-3; UWHP, KGC, 39/I, Howard Barrell interview with Naledi Tsiki, 5 Dec. 1990, 1267-9; UWHP, KGC, 25/III, 'Mosima Sexwale, deposition to the SA Police', 4 Feb. 1977, 16, 18-9; UWHP, KGC, 26/III, 'Naledi Tsiki, deposition to the SA Police', 3 Feb. 1977, 79.

${ }^{10}$ UWHP, PT, Box 60, The State Versus MG Sexwale and others, Court Record vol. 1, Testimony of Charles Buthelezi, 16 Jan. 1978, p.31; UWHP, KGC, 25/III, 'Mosima Sexwale, deposition to the SA Police', 4 Feb. 1977, 17-8, 20; UWHP, KGC, 26/III, 'Naledi Tsiki, deposition to the SA Police', 3 Feb. 1977, 8-10.

${ }^{11}$ UWHP, KGC, 25/III, 'Mosima Sexwale, deposition to the SA Police', 4 Feb. 1977, 19-20, 42-3, 45 -

6; UWHP, KGC, 26/III, 'Naledi Tsiki, deposition to the SA Police', 3 Feb. 1977, 10-12.

${ }^{12}$ UWHP, KGC, 25/III, 'Mosima Sexwale, deposition to the SA Police', 4 Feb. 1977, 39-42; UWHP, KGC, 26/III, 'Naledi Tsiki, deposition to the SA Police', 3 Feb. 1977, 18-9.

${ }^{13}$ UWHP, KGC, 25/III, 'Mosima Sexwale, deposition to the SA Police', 4 Feb. 1977, 31-6.

${ }^{14}$ UWHP, KGC, 25/III, 'Mosima Sexwale, deposition to the SA Police', 4 Feb. 1977', 21-31, 43-4; UWHP, KGC, 26/III, 'Naledi Tsiki, deposition to the SA Police', 3 Feb. 1977, 14-8.

${ }^{15}$ UWHP, KGC, 25/III, 'Mosima Sexwale, deposition to the SA Police', 4 Feb. 1977, 21; University of Cape Town Manuscripts and Archives (hereafter UCT), Simons Collection BC 1081 (hereafter SC), P29.2, R. Kasrils, W. Anderson and others, 'MCW (ANC Confidential Training Leaflet)' c.1988-89, 45, 11-14, 29-30.

${ }^{16}$ UCT, SC, P29.2, Kasrils, Anderson and others, 'MCW', 8-11, 14-9, 25-6.

${ }^{17}$ UWHP, KGC, 25/III, 'Mosima Sexwale, deposition to the SA Police', 4 Feb. 1977, 36-9; UWHP, KGC, 26/III, 'Naledi Tsiki, deposition to the SA Police', 3 Feb. 1977, 12-4. 
${ }^{18}$ UCT, SC, P29.2, Kasrils, Anderson and others, 'MCW', 4-7, 10, 19, 29-33, 35-7.

${ }^{19}$ UWHP, KGC, 26/III, 'Naledi Tsiki, deposition to the SA Police', 3 Feb. 1977, 15, 17.

${ }^{20}$ UWHP, KGC, 25/III, 'Mosima Sexwale, deposition to the SA Police', 4 Feb. 1977, 46.

${ }^{21}$ UWHP, KGC, 39/I, Howard Barrell interview with Naledi Tsiki, 26 Nov. 1990, 1253-5.

${ }^{22}$ UWHP, KGC, 39/I, Howard Barrell interview with Naledi Tsiki, 26 Nov. 1990, 1252.

${ }^{23}$ UWHP, KGC, 23/III, Stanley Nkosi, 'Confession,' 23 Apr. 1976, 3-4; UWHP, KGC, 23/III,

Deposition to police by Stanley Nqobizizwe Nkosi, 19 July 1976, 4-7; University of the Witwatersrand Historical Papers, AD1901 Political Trials, Box 62, The State Versus MG Sexwale and others, Court Record vol. 26, Testimony of Ian Deway Rwaxa, 10 Feb. 1978, pp.1228-9.

${ }^{24}$ UWHP, KGC, 39/I, Howard Barrell interview with Naledi Tsiki, 5 Dec. 1990, 1269

${ }^{25}$ UWHP, PT, 65/19, The State Versus MG Sexwale and others, Judgement by J. Myburgh, 5 Apr. 1978, 2270; University of the Witwatersrand Historical Papers, AD1901 Political Trials, Box 62, The State Versus MG Sexwale and others, Court Record vol. 25, Testimony of Ian Deway Rwaxa, 9 Feb. 1978, pp.1163-4.

${ }^{26}$ UWHP, KGC, 23/III, Stanley Nkosi, 'Confession,' 23 April 1976, 4-5; UWHP, KGC, 23/III, Deposition to police by Stanley Nqobizizwe Nkosi, 19 July 1976, 7-9, 13-4.

${ }^{27}$ UWHP, KGC, 23/III, Stanley Nkosi, 'Confession,' 23 April 1976, 5; UWHP, KGC, 23/III, Petrus Motlanthe, 'Confession,' 24 April 1976, 3, 5-7; UWHP, KGC, 23/III, Deposition to police by Stanley Nqobizizwe Nkosi, 19 July 1976, 2, 10-15. 